\title{
Innovative operation of microbial fuel cell-based biosensor for selective monitoring of acetate during anaerobic digestion
}

Sun, Hao; Zhang, Yifeng; Wu, Shubiao; Dong, Renjie; Angelidaki, Irini

Published in:

Science of the Total Environment

Link to article, DOI:

10.1016/j.scitotenv.2018.11.336

Publication date:

2019

Document Version

Peer reviewed version

Link back to DTU Orbit

Citation (APA):

Sun, H., Zhang, Y., Wu, S., Dong, R., \& Angelidaki, I. (2019). Innovative operation of microbial fuel cell-based biosensor for selective monitoring of acetate during anaerobic digestion. Science of the Total Environment, 655, 1439-1447. https://doi.org/10.1016/j.scitotenv.2018.11.336

\section{General rights}

Copyright and moral rights for the publications made accessible in the public portal are retained by the authors and/or other copyright owners and it is a condition of accessing publications that users recognise and abide by the legal requirements associated with these rights.

- Users may download and print one copy of any publication from the public portal for the purpose of private study or research.

- You may not further distribute the material or use it for any profit-making activity or commercial gain

- You may freely distribute the URL identifying the publication in the public portal 


\section{Accepted Manuscript}

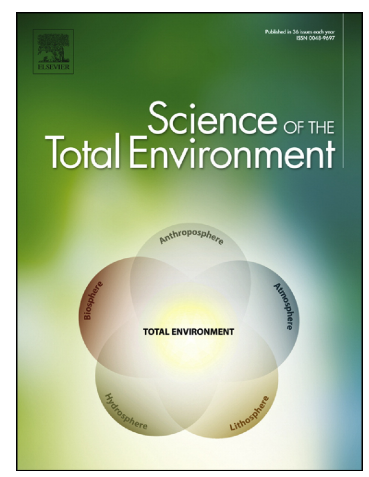

Hao Sun, Yifeng Zhang, Shubiao Wu, Renjie Dong, Irini Angelidaki

Innovative operation of microbial fuel cell-based biosensor for selective monitoring of acetate during anaerobic digestion

PII: S0048-9697(18)34693-X

DOI: https://doi.org/10.1016/j.scitotenv.2018.11.336

Reference: STOTEN 29685

To appear in: Science of the Total Environment

Received date: 27 October 2018

Revised date: 22 November 2018

Accepted date:

22 November 2018

Please cite this article as: Hao Sun, Yifeng Zhang, Shubiao Wu, Renjie Dong, Irini Angelidaki, Innovative operation of microbial fuel cell-based biosensor for selective monitoring of acetate during anaerobic digestion. Stoten (2018), https://doi.org/10.1016/ j.scitotenv.2018.11.336

This is a PDF file of an unedited manuscript that has been accepted for publication. As a service to our customers we are providing this early version of the manuscript. The manuscript will undergo copyediting, typesetting, and review of the resulting proof before it is published in its final form. Please note that during the production process errors may be discovered which could affect the content, and all legal disclaimers that apply to the journal pertain. 


\title{
Innovative operation of microbial fuel cell-based biosensor for
}

\section{selective monitoring of acetate during anaerobic digestion}

\author{
Hao Sun ${ }^{\mathrm{a}, \mathrm{b}}$, Yifeng Zhang ${ }^{\mathrm{b}, *}$, Shubiao $\mathrm{Wu}^{\mathrm{a}, \mathrm{c}, *}$, Renjie Dong ${ }^{\mathrm{a}}$, Irini Angelidaki ${ }^{\mathrm{b}}$
}

${ }^{a}$ College of Engineering, China Agricultural University, Key Laboratory for Clean Renewable Energy Utilization Technology, Ministry of Agriculture, Beijing 100083, P. R. China

${ }^{\mathrm{b}}$ Department of Environmental Engineering, Building 113, Technical University of Denmark, DK-2800 Lyngby, Denmark

${ }^{\mathrm{c}}$ Aarhus Institute of Advanced Studies, Aarhus University, Høegh-Guldbergs Gade 6B, DK-8000 Aarhus C, Denmark

*Corresponding author

Dr. Yifeng Zhang

Tel: (+45) 45251410; fax: (+45) 45933850;

E-mail address: yifz@env.dtu.dk; yifzmfc@gmail.com

Dr. Shubiao Wu

Tel.: (+86) 10-62737852; fax: (+86) 10-62737885;

E-mail address: wushubiao@gmail.com 


\section{Abstract}

Volatile fatty acids (VFAs) especially acetate concentration have been proved to be a sensitive and reliable indicator for many anaerobic processes such as anaerobic digestion (AD). Microbial fuel cells (MFC) have been demonstrated as a promising VFAs sensor due to simple reactor design and operating conditions among microbial electrochemical biosensors. However, the conventional MFC biosensors may fail to distinguish between VFAs and other organics as real digestates containing complex organics and microbes are fed into anode directly. In the present study, an MFC based biosensor was developed and operated in a smart way for selective acetate detection. In the biosensor, acetate ions contained in the AD sample was first fed into the cathode, and then acetic ion transferred through the membrane from the cathode to anode chamber where it was further used as the sole substrate by pre-enriched electroactive biofilm for the current generation. A linear correlation between the current density and acetate concentrations $(0.5-20 \mathrm{mM})$ at varied reaction time (1 - 5 hours) was established. Then, the interference from propionate, butyrate, isobutyrate, and glucose on the performance of the biosensor was evaluated. Furthermore, the influence of sample temperatures $\left(37\right.$ and $\left.55^{\circ} \mathrm{C}\right)$ was also studied. Finally, the VFAs content in real AD effluent with this biosensor was measured. The results corresponded well with gas chromatographic measurements. This simple, and reliable biosensor could serve as a promising alternative method for acetate detection in the $\mathrm{AD}$ process or any other acetate-rich fluids.

Keywords: Bioelectricity; Acetate; Anaerobic digestion; Microbial fuel cell; Biosensor; Current 


\section{Introduction}

Anaerobic digestion (AD) technology has attracted worldwide attention due to its unique merits in organic wastes treatment and green energy production [1]. AD processes are sensitive to variations of the operating parameters such as temperature, $\mathrm{pH}$, feed amount and composition, and so on [2]. Thus, monitoring and control are essential for preventing the poor operational stability of the AD process. Therefore, reliable indicators are needed. Volatile fatty acids (VFAs) concentrations have been proven as a sensitive and reliable indicator for AD processes [3]. Moreover, individual VFAs detection could give more specific information for process diagnosis [4]. Generally, acetate, usually constitute the biggest proportion of total VFAs in the AD process, is measured by gas or liquid chromatography that is expensive, time-consuming, mostly offline and usually not available at AD plants. Therefore, the development of a biological acetate sensing system with the potential of being online, accurate and cost-effective is an attractive alternative.

The application of microbial bioelectrochemical systems (BES) as a biosensor for water quality measurement (e.g., biochemical oxygen demand, toxic components, and acid rain detection) has attracted great interest in recent years [5-13]. The BES sensors have great potential for onsite and real-time monitoring with rapid and simple testing [14]. Moreover, BES sensors are based on anodic biofilm that oxidizes organic substrates as living and self-regenerating recognition element which could bring several advantages, such as cost-effective, long-time stable and environmental friendly [15-16]. Recently, the feasibility of varied BES including microbial fuel cell (MFC), microbial desalination cell (MDC) and microbial electrolysis cell (MEC) have been demonstrated for online monitoring of VFAs during AD process [15, 17-19]. In particularly, the MFC sensor has more simple design and operating conditions among all BES biosensors for VFAs detection [17-18]. However, MFC biosensors still have challenges that need to be addressed before commercialization. 
For instance, it may fail to distinguish between VFAs and other organics due to change of microbial communities when real digestates are fed into anode directly. It has been recently found that sending digestate into the middle of MDC or cathode of MEC could avoid the disturbance from other organics and microorganisms contained in the digestate $[15,19]$. Extended detection range was also observed since VFAs need to transport from another side of the membrane into anode which creates the concentration gradient. We hypothesized that MFC biosensor could achieve the same goals by receiving digestate in cathode chamber instead of the anode, for which feasibility has never been explored. Furthermore, MFC sensors could also be developed for individual VFAs detection, by enrichment of anodic biofilm metabolizing a specific VFAs. If successful, MFC biosensors could greatly reduce the capital and operating costs (e.g., no need external power supply which is prerequisite for MEC sensor) on individual VFAs detection, compared to other BES sensors.

In the present study, we propose an innovative bioelectrochemical sensor for acetate measurement composed by a two-chamber MFC, in which individual acetate ions in digestate move from cathode to anode for bacterial oxidation and current generation. To the best of our knowledge, such a way of running MFC for acetate detection has never been reported. To demonstrate the feasibility, the current response of the MFC biosensor to various acetate concentrations in the synthetic wastewater (simulating AD effluent) was evaluated. Subsequently, the interference of other VFAs such as propionate, butyrate, and isobutyrate, complex organic matter such as glucose, and the initial temperature of the sample on the performance of the sensor was investigated. Finally, effluent from a CSTR fed with cow manure was tested to verify the reliability of the biosensor. The simple biosensor showed promising potential in online monitoring of acetate concentrations. The outcomes would benefit the AD process monitoring and optimization and also expand the application of microbial electrochemical systems. 


\section{Material and methods}

\subsection{Biosensor setup and operation}

A bio-electrochemical reactor consisting of two chambers, made of nonconductive polycarbonate plates, was used in this study. As shown in Figure 1, two chambers with the equal dimensions (8 $\mathrm{cm} \times 8 \mathrm{~cm} \times 4 \mathrm{~cm}$ ) were physically separated by an anion exchange membrane (AEM) (AMI 7001, Membrane international, NJ, $9 \mathrm{~cm} \times 9 \mathrm{~cm})$. The membrane was soaked overnight in $5 \% \mathrm{NaCl}$ solution and then stored in deionized water before use. Eight stainless screws are used to assemble the plates which were sealed with rubber gaskets preventing leakage. Inserted rubber tubes were prepared for medium refilling, aeration, and sampling. The anode electrode was made of carbon fiber brush $(5.0 \mathrm{~cm}$ in diameter, $7.0 \mathrm{~cm}$ in length, Mill-Rose, USA), which has been heat-treated in a muffle furnace at $450^{\circ} \mathrm{C}$ for $30 \mathrm{~min}$ [20]. The cathode electrode was a graphite plate $(4.2 \mathrm{~cm} \times 4.2$ $\mathrm{cm}$ ) coated with $0.5 \mathrm{mg} \mathrm{cm}^{-2} \mathrm{Pt}$. Two electrodes were connected through a $10 \Omega$ external resistance except at the biofilm enrichment stage (use $1000 \Omega$ external resistance).

To enrich exoelectrogenic biofilm on the electrode, the anode was first inoculated with domestic wastewater collected from primary clarifier (Lundtofte Wastewater Treatment Plant, Lyngby, Denmark). After twice refilling with wastewater, the anode chamber was filled with $15 \mathrm{mM}$ acetate in buffer solution $(\mathrm{pH}=7.25 \pm 0.04)$ containing $50 \mathrm{mM}$ phosphate buffer $\left(\mathrm{Na}_{2} \mathrm{HPO}_{4}, 4.33 \mathrm{~g} \mathrm{~L}^{-1}\right.$ and $\left.\mathrm{NaH}_{2} \mathrm{PO}_{4}, 2.03 \mathrm{~g} \mathrm{~L}^{-1}\right)$ and nutrient solution $\left(\mathrm{NH}_{4} \mathrm{Cl}, 0.31 \mathrm{~g} \mathrm{~L}^{-1} ; \mathrm{KCl}, 0.13 \mathrm{~g} \mathrm{~L}^{-1} ; 12.5 \mathrm{~mL}\right.$ mineral solution and $12.5 \mathrm{~mL}$ vitamin solution) [21] to acclimate the bacterial consortia. Ferricyanide solution $(50 \mathrm{mM})$ was added in the cathode chamber as the electron acceptor. Instead, oxygen can be used in future to avoid chemical purchase and disposal. During this enrichment period, a $1000 \Omega$ external resistance was used to connect the two electrodes. The solution in both chambers was 
replaced for every 8-10 days when the voltage became lower than $50 \mathrm{mV}$. After about three months of enrichment, the voltage from this system was stabilized at around $650 \mathrm{mV}$, which indicated that mature electrochemically active biofilm has attached to the surface of the anode and ready for the sensing experiment.

All experiments were conducted at batch mode. For each batch experiment, the anode chamber was filled with approximately $250 \mathrm{~mL}$ buffer solution $(\mathrm{pH}=7.25 \pm 0.04)$ containing $50 \mathrm{mM}$ phosphate buffer and nutrient solution as previously described [19]. The anolyte was renewed for each batch test to maintain the same initial condition. The cathode was filled with about $250 \mathrm{~mL}$ of synthetic wastewater which was prepared from a modified basic anaerobic (BA) medium (omitted the stock solutions $\mathrm{C}$ and $\mathrm{E}$ ) containing varying concentrations of sodium acetate [22]. The anode was purged with $\mathrm{N}_{2}$ for 10 min to maintain the anaerobic environment before each batch, while the cathode was continuously aerated with the flow rate around $50 \mathrm{~mL} \mathrm{~min}^{-1}$. Every batch experiment was run for 5 $\mathrm{h}$ at room temperature $\left(22 \pm 2^{\circ} \mathrm{C}\right)$.

\subsection{Electrochemical analyses and calculations}

Conductivity was measured using a CDM 83 conductivity meter (Radiometer) and pH was measured by a PHM $210 \mathrm{pH}$ meter (Radiometer). VFAs concentrations were measured using a GC with FID detection (Thermo Scientific, TRACE1300). The voltage across the resistance was monitored using a virtual instrument based data logging system (National Instrument, LabVIEW 2012) combined with an analog signal acquisition card (USB 3252, ZLAD, China). The voltage signal was acquired every second and average voltage per minute was recorded. The current was calculated according to Ohm's law. The current density $i\left(\mathrm{~A} \mathrm{~m}^{-2}\right)$ was calculated as follows:

$$
i=I / A
$$


where, $I(\mathrm{~A})$ is the current and $A\left(\mathrm{~m}^{-2}\right)$ is the projected surface area of the cathode electrode.

\section{Results and discussion}

\subsection{Response of current density to various acetate concentrations}

The current density generated at different acetate concentrations was investigated. A typical current density time course at different acetate concentrations is shown in Figure 2. Generally, the current density increased with time. This increase of current can be attributed to acetate. Acetate was transferred from cathode chamber to anode chamber where it was oxidized delivering electrons for electricity generation. No other substrates were present which could account for the electricity generation in the anode chamber. The current density increased gradually and reached a maximum value at the end of the batch test $(5 \mathrm{~h})$ when the initial acetate concentration was lower than $40 \mathrm{mM}$ (Figure 2A). The acetate transport through the membrane would be faster than its consumption by the biofilm, which leads to the accumulation of acetate in the anode chamber along with reaction time and initial acetate concentration. Then, the biosensor would approach saturated state due to the rising acetate compared to the limited oxidation capability of biofilm in the anode chamber [23].

The current density was higher at higher initial acetate concentration. The current increased sharply at the beginning of the experiments (Figure 2B). The sharp initial increase could be explained by three reasons: firstly, due to acetate carry-over effect, which could be directly used by the biofilm; secondly, bacteria are able to store intracellularly compounds in the form of polymers (such as poly- $\beta$-hydroxybutyrate) and use them as carbon and energy sources during this period [24]; thirdly, the higher acetate transport rate through the membrane due to initial higher concentration gradient. In some cases, a sudden drop of the current in the first few minutes of the batch experiment was observed. This sudden current drop might due to the capacitive property of exoelectrogens which 
store the electrons in the anode electrode from microbial oxidation of substrate during open circuit situations (refill solution of two chamber) and then release them during closed circuit [25-27]. The increase of current at the late stage of the batch experiment indicated that the biosensor was approaching saturation. This is in accordance with a previous study, in which current density increased more sharply and reached to maximum stable value in a shorter time at higher total VFAs concentrations compared to at lower concentrations [19]. The fluctuation of the saturation current may be due to the minor difference in the experimental conditions (such as the aeration rate, the electrode distance) in different batch experiments. Since $10 \Omega$ external resistance was used in this biosensor, which was even lower than the internal resistance making the system sensitive to changes and resulting in relatively large deviations in the current [19].

The response of biosensor current to different acetate concentrations at specific reaction time (at 1 , 2, 3, 4 and 5 hour) are shown in Figure 3A. The increments in current densities under high initial acetate concentrations were lower than that of relatively lower acetate concentrations at the same reaction time. A nonlinear relationship between the current densities and the initial acetate concentrations along with different reaction times were observed, which fit well with an exponential regression in function of $y=a^{*}\left(1-b^{\wedge} x\right)$. The coefficients of this nonlinear regression with different reaction time ( $1-5$ hours) are $0.83,0.93,0.98,0.99$, and 0.98 , respectively. The nonlinear response might because of the biosensor is saturated due to the accumulation of acetate in the anode which would result in maximum current output even at relatively low acetate concentrations in the anode chamber (i.e., $2.3 \mathrm{mM}$ and $3.2 \mathrm{mM}$ ) [28-29]. More reliable and accurate results could be obtained from longer reaction time as the average relative standard deviation was $43.9 \%, 26.6 \%$, $17.0 \%, 13.4 \%$, and $11.7 \%$ at a reaction time of 1 to 5 hour, respectively. However, linearity response is always being pursued from the aspect as a sensor. 
As shown in Figure $3 \mathrm{~B}$ and Figure $\mathrm{S} 2$, the current densities of biosensor showed a linear relationship with the initial acetate concentration $(\leq 20 \mathrm{mM})$ at reaction time from 1 to 5 hours $\left(\mathrm{R}^{2}\right.$ $=0.99$ ). Moreover, the linearity range of this biosensor could extend to $40 \mathrm{mM}$ at a reaction time of 1 and 2 hours $\left(\mathrm{R}^{2}=0.99,1.00\right.$, respectively) (Figure $\mathrm{S} 1$ ). The average relative standard deviation with the acetate concentration from 0.5 to $40 \mathrm{mM}$ at different reaction time (from 1 to 5 hour) was $57.4 \%, 36.5 \%, 24.4 \%, 19.0 \%$, and $16.7 \%$, respectively. The linear growth of the current density could be maintained under the condition that the acetate accumulated in the anode chamber was far below the saturated concentration, for instance, under low initial concentration $(<20 \mathrm{mM})$ condition. Longer reaction time would accumulate more acetate in the anode chamber assuming that the diffusion rate through the membrane is higher than the reaction rate for degradation of acetate in the anode. Moreover, higher initial concentration also promote acetate accumulation. Therefore, at long reaction time and at high initial acetate concentrations, the possibility of exceeding acetate saturation limits in the anode was high. However, the minimum relative standard deviation was obtained at the longest reaction time $(5 \mathrm{~h})$, which means longer reaction time improve the accuracy of this biosensor. Therefore, 5 hour reaction time was suggested, even the upper limit for a linear response range would be lowered to $20 \mathrm{mM}$.

The results demonstrate the feasibility of this biosensor for accurate acetate measurement in the range from 0.5 to $20 \mathrm{mM}$ with 5 hours response time. For practical applications however, 5 hours measuring time would be adequate for acetate monitoring in the $\mathrm{AD}$ processes which often have hydraulic retention times in the range of 15-30 days. Therefore, monitoring of acetate a few times per day would be enough for adequate process monitoring. Even though, a quick response is always being expected from a sensor. The requirement of reaction time from 3 to 5 hours to ensure satisfactory measurement result appears to be rather slow compared to small-scale continuous flow MFC sensors. The main reason is the fact that the sample was added in cathode chamber that takes 
time for acetate transfer through the membrane and being utilized for the current generation. It might also be related to the "large scaled" MFC reactor (about $500 \mathrm{~mL}$ ) which contains two chambers with equal dimensions $(8 \mathrm{~cm} \times 8 \mathrm{~cm} \times 4 \mathrm{~cm})$. Therefore, more efforts are needed in the future to accelerate the response of the biosensor.

Acetate concentration in $\mathrm{AD}$ process could easily over $20 \mathrm{mM}$ [30]. Thus, detection of acetate at a larger range is still needed. Dilution of samples can be seen as one alternative solution to extend the biosensor detection range. Moreover, with such a sensor structure, the acetate can be consumed by aerobes in the cathode chamber. Obvious growth of aerobes in cathode has been observed after more than two weeks. Thus, the cathode chamber was cleaned per week to minimize the growth of internal aerobes. Furthermore, this issue could also be avoided in short test time. Therefore, further efforts are needed to obtain an accurate measurement within a short time.

\subsection{Changes in $\mathrm{pH}$ and conductivity}

The variations of $\mathrm{pH}$ and conductivity in both chambers during each batch test under varies initial acetate concentrations are shown in Figure 4. In the anode chamber, $\mathrm{pH}$ slightly decreased from $7.25 \pm 0.04$ to $7.22 \pm 0.07$ during all the batch runs (Figure $4 \mathrm{~A}$ ), which would not affect the performance of the biosensor. The decrease of $\mathrm{pH}$ mainly due to the proton generated from the microbial activities, but the high buffer capacity of the phosphate solution minimized $\mathrm{pH}$ change and maintained a suitable environment for exoelectrogens. As shown in Figure 4C, $\mathrm{pH}$ in the cathode chamber increased from $8.22 \pm 0.13$ to $8.79 \pm 0.21$ on average, which was mainly due to the cathodic oxygen reduction. However, in this short period $(5 \mathrm{~h})$, this increase of $\mathrm{pH}$ would have no significant effect on biosensor performance [31-32]. As reported, MFC performance would improve with the increase of conductivity of the solution (ionic strength) which lead to lower internal resistance [23, 33-34]. The variation of conductivity in the anode chamber is shown in 
Figure 4B. It varied from $6.68 \pm 0.06$ to $6.66 \pm 0.15 \mathrm{mS} \mathrm{cm}^{-1}$ in all batches. The conductivity in the cathode chamber increased from $5.42 \pm 0.05$ to $12.91 \pm 0.16 \mathrm{mS} \mathrm{cm}^{-1}$ along with increasing initial acetate concentrations $(0.5$ to $120 \mathrm{mM})$ in the synthetic AD effluent (Figure 4D). After 5 hours of operation, the conductivity of catholyte decreased to $5.27 \pm 0.76 \%$ on average. In this case, the conductivity of the solutions would no significantly influence the biosensor performance.

\subsection{Effect of propionate, butyrate, isobutyrate and glucose on the biosensor performance}

In this study, the biofilm on the anode was expected to react specifically to acetate since it was enriched with acetate as a sole carbon source for about three months. Meanwhile, a wide range of soluble or dissolved complex organic matter has been demonstrated to be used as substrates in MFC reactors [35]. VFAs and other organic matter such as lipids and proteins, commonly present in AD effluents, might be used as potential substrates by the anode biofilm and create noise to the sensor signal. Thus, it is of particular interest to examine the effect of these interfering components on the biosensor performance for establishing the selectivity of this biosensor [16].

To test the selectivity of the biosensor, we dosed other organic compounds (glucose, propionate, butyrate, isobutyrate propionate, butyrate, isobutyrate) instead of acetate into the cathode chamber. As shown in Figure 5A, almost no electricity was produced during the 5 hours reaction, when 20 $\mathrm{mM}$ glucose was added in the cathode chamber. This could be explained by the nonionic characteristics of glucose which doesn't permit its transport through AEM [15]. Similarly, we can assume that other nonionic complex organic matter (such as lipid and protein) would not result in any response [15, 19].

To investigate the effect of propionate, iso-butyrate and butyrate on the biosensor performance, 20 
$\mathrm{mM}$ of these compounds, were used as substrates in the cathode chamber. In this batch test, the current density with the $20 \mathrm{mM}$ of acetate was $0.843 \pm 0.065 \mathrm{~A} \mathrm{~m}^{-2}$ (Figure 5), which was lower than that of the average value $\left(1.032 \pm 0.155 \mathrm{~A} \mathrm{~m}^{-2}\right)$ for the whole experiment period (Figure 3). The possible explanation could be the variation of the biofilm activity due to the temperature change (from summer to autumn) and membrane fouling after long-term operation. Experiment data from the same conditions were chosen for comparison. The current densities of the biosensor increased slightly during the batch experiment with the other VFAs and achieved $0.181 \pm 0.008 \mathrm{~A}$ $\mathrm{m}^{-2}$ (propionate), $0.033 \pm 0.001 \mathrm{~A} \mathrm{~m}^{-2}$ (iso-butyrate), and $0.053 \pm 0.009 \mathrm{~A} \mathrm{~m}^{-2}$ (butyrate) after 5 hours' reaction time (Figure 5A). The current densities at the end of the batch experiment with 20 $\mathrm{mM}$ of propionate, iso-butyrate, and butyrate were $21.52 \%, 3.60 \%$, and $6.31 \%$ compared to the current density from same concentration of acetate. This is consistent with previously reported by Kretzschmar et al. (2017), in which, butyrate and propionate resulted in a slight response [16]. The other VFAs were probably also transferred through the membrane to the anode and were used as a substrate for the current generation. However, the diffusion rate of other VFAs might lower than acetate, since lighter weight molecules will transport faster than heavier molecules. Even though the biosensor could still respond to other VFAs but nothing like as sensitive as it is to acetate. The application of the suitable nanofiltration membrane might be an alternative solution to further improve the specificity of the acetate biosensor [36]. For practical situation, propionate, iso-butyrate and butyrate are often present at much lower in digested slurry concentrations than the ones tested in the present study, which will further decrease the possible overestimation caused by the other VFAs. Although the selectivity of the biosensor to acetate is not perfect, it is still feasible for the purposes of $\mathrm{AD}$ process monitoring.

Nevertheless, propionate, iso-butyrate and butyrate are also able to be used by exoelectrogens after acclimation. Long-term exposure of propionate, iso-butyrate and butyrate to the anode might induce 
a higher current. Therefore, efforts in maintaining the stability of the biofilm are needed, such as shorten the reaction time and using a selective membrane. On the other hand, the development of a biosensor for monitoring other substrates could be an interesting topic in the future.

\subsection{Effect of initial sample temperature on the biosensor performance}

It is well known that bacterial activities are affected by temperature variation. Moreover, mass transfer and oxygen reaction rates catalyzed by Pt on the cathode are also affected by temperature [37]. Obviously, changes in temperature could influence MFC performance, especially for monitoring samples taken from thermophilic or mesophilic AD reactors. Therefore, the effect of sample temperature on the biosensor performance was investigated by adding a solution containing $20 \mathrm{mM}$ acetate with different initial temperatures in the cathode chamber, while maintaining the other condition same as the other batch assays. Initial temperatures of $37^{\circ} \mathrm{C}$ and $55^{\circ} \mathrm{C}$ were chosen for simulating $\mathrm{AD}$ effluents from mesophilic and thermophilic conditions. There was no temperature control in both chambers. The effect of sample temperature on the anodic biofilm could be neglected. Firstly, though the samples had an initial temperature of 37 or $55^{\circ} \mathrm{C}$, the actual temperature in the cathode would be much lower and would quickly drop to ambient temperature. Secondly, $55^{\circ} \mathrm{C}$ much blows the pasteurization temperature $\left(72^{\circ} \mathrm{C}\right)$. Thirdly, biofilm cells are more resistant to high temperature than planktonic cells.

As shown in Figure $5 \mathrm{~B}$, at the initial temperature of $55^{\circ} \mathrm{C}$, the current generation increased during the batch experiment. The final current density after 5 hours was approximately $25.95 \%$ higher compared to the current density at $22^{\circ} \mathrm{C}$. Meanwhile, no obvious improvement of the current production was observed when the temperature was $37^{\circ} \mathrm{C}$. Since the solution we tested was added into the cathode chamber, and therefore the temperature at the anode chamber and the anodic biofilm activity would not be affected significantly. This is in accordance with the previous 
reporting that the reactor performance was similar when the temperature was increased from $30^{\circ} \mathrm{C}$ to $37^{\circ} \mathrm{C}$ [37-38]. Another aspect to consider is the improved mass transfer in the cathode chamber at $55^{\circ} \mathrm{C}$, which might have affected the current density. Thus, there would be no significant effect on the performance of this biosensor system when the digestates of $37^{\circ} \mathrm{C}$ are used in practical applications. However, the temperature should be lowered before analysis when the effluent is from thermophilic reactors, as this is necessary to obtain an accurate result. For practical application, the time of cooling is not really an issue in a 5-hour assay. Moreover, the high temperature can be lowered by simply mixing the sample with other liquid before adding to the reactor.

\subsection{Verification of the biosensor with AD effluent}

The acetate biosensor was finally tested with AD effluent from a 10 L CSTR fed with cow manure to verify its applicability. Three samples were used in this test; one is original AD effluent (Table 1) while the other two were same AD effluent amended with extra 10 and $15 \mathrm{mM}$ acetate. The variation of current density along with experiment time was shown in Figure 6A. A reverse of current direction at the beginning of the experiment was observed. This was probably due to the microbial activity of the added $\mathrm{AD}$ effluent at the cathode [18, 39]. The average value from duplicate tests is shown in Figure 6B. The acetate concentration in the AD effluent was compared to GC measurements. The sensor measured acetate concentration of the original AD effluent was in good agreement with the GC measured value, while the samples with added acetate were a bit lower.

Meanwhile, another similar biosensor system with a slightly larger size of the cathode electrode (5.2 $\mathrm{cm} \times 5.2 \mathrm{~cm}$ ) was operated to investigate the long-term stability for AD effluent measurement. A typical current density time course, at different acetate concentrations, is shown in Figure 7. As shown in Figure 7A, after about two weeks test with the AD effluent, biofilm growth on the surface 
of the cathode electrode was observed (Figure S3) which prevented current generation in the following test [40]. However, the sensor performance recovered when the cathodic biofilm was removed (Figure 7A). This indicates that routine maintenance of the biosensor system, such as cleaning every two weeks, would be necessary to guarantee the performance. Alternatively, the growth of cathodic biofilm could be avoided if using a three compartment MFC (cathode, anode, and sample chamber) with the same type of anionic membrane to separate the anode and sample chamber. From Figure 7B, it can be concluded that calculated acetate concentrations based on $5 \mathrm{~h}$ reaction times are concentrations closest to the reference value, which indicates that longer reaction times are increasing the biosensors accuracy. As shown in Figure S4, the linear relationship between the current densities and initial acetate concentration at 3, 4 and 5 hours could also be established. It can be deduced that this biosensor is a quite promising alternative way for acetate detection in $\mathrm{AD}$ effluent.

\subsection{Perspectives}

BES based biosensors have attracted increasing interest in recent years. A brief summary of biosensors for VFAs monitoring is shown in Table 2. In comparison to these biosensors, the main advantages of the proposed MFC biosensor can be listed as: a, wider linear dynamic range of the current densities corresponding to the acetate concentration has been obtained; $b$, simple structure consist of two chambers separated by AEM which could reduce capital investment and avoid the influence on anode from the microorganisms; c, only the voltage across the external resistance was monitored as sensor signal; d, simple operation by adopt the strategy that running reactor with non-sterile, non-agitated, and under room temperature condition. On the contrary, disadvantages could not be ignored: minor interference from other VFAs still cannot be eliminated; aerobic bacteria which could consume acetate would grow in cathode chamber without proper maintenance; 
the chemical requirement; and the detection range also needs to be extended. Nevertheless, despite the remaining challenges MFC based biosensor, seem to be promising and could serve as a simple tool for acetate detection and further optimized the AD process for organic waste treatment and bioenergy production. The feasibility of MFC based biosensor for acetate monitoring with the sample added to the cathode chamber has been demonstrated in current work. Further improvements before its onsite application can be conducted from the flowing aspects: shortening the reaction time, reducing reactor volume and the chemical requirement, eliminating the requirements of cathode platinum catalyst. Moreover, continuous operation and using nanoporous (anionic) membrane that only allows acetate to pass through could be effective ways to address the challenges in response time and sensor selectivity.

\section{Conclusions}

The present work demonstrated the feasibility of MFC-typed sensor for acetate detection in the AD process. The sensor is constituted by a traditional double-chamber MFC reactor with AEM. The key sensing element is a matured electroactive biofilm enriched with the acetate as the sole carbon source. A linear relationship between current densities and initial acetate concentrations (0.5 to 20 $\mathrm{mM}$ ) was obtained. The biosensor showed high selectivity since only the anions could transport through the AEM and then be utilized for the current generation. The interference from other VFAs was very limited. Sample temperature of $37^{\circ} \mathrm{C}$ would not significantly affect the biosensor performance, but the temperature should be lowered before analysis when the effluent is from thermophilic reactors. The proposed biosensor does have a potential in AD process monitoring, but a further improvement to extend detection range, reduce the maintenance and be more robust is still needed to fit the practical application situation. 


\section{Acknowledgements}

The work was supported by The Danish Council for Independent Research (DFF-1335-00142) and Novo Nordisk Foundation (NNF16OC0021568). We likewise greatly appreciate the support of the China Scholarship Council (CSC) and the critical and constructive comments from the anonymous reviewers who have helped improve this manuscript. 


\section{References:}

[1] C. Mao, Y. Feng, X. Wang and G. Ren, Review on research achievements of biogas from anaerobic digestion, Renewable and Sustainable Energy Reviews (2015) 540-555.

[2] I. Vanwonterghem, P.D. Jensen, D.P. Ho, D.J. Batstone and G.W. Tyson, Linking microbial community structure, interactions and function in anaerobic digesters using new molecular techniques, Curr Opin Biotech (2014) 55-64.

[3] K. Boe, D.J. Batstone, J. Steyer and I. Angelidaki, State indicators for monitoring the anaerobic digestion process, Water Res 20 (2010) 5973-5980.

[4] B.K. Ahring, M. Sandberg and I. Angelidaki, Volatile fatty acids as indicators of process imbalance in anaerobic digestors, Appl Microbiol Biot 3 (1995) 559-565.

[5] Y. Jiang, P. Liang, C. Zhang, Y. Bian, X. Yang, X. Huang and P.R. Girguis, Enhancing the response of microbial fuel cell based toxicity sensors to $\mathrm{Cu}$ (II) with the applying of flow-through electrodes and controlled anode potentials, Bioresource Technol (2015) 367-372.

[6] J. Sun, G.P. Kingori, R. Si, D. Zhai, Z. Liao, D. Sun, T. Zheng and Y. Yong, Microbial fuel cell-based biosensors for environmental monitoring: a review, Water Sci Technol 6 (2015) 801-809.

[7] M. Di Lorenzo, A.R. Thomson, K. Schneider, P.J. Cameron and I. Ieropoulos, A small-scale air-cathode microbial fuel cell for on-line monitoring of water quality, Biosensors and Bioelectronics (2014) 182-188.

[8] Y. Zhang and I. Angelidaki, A simple and rapid method for monitoring dissolved oxygen in water with a submersible microbial fuel cell (SBMFC), Biosensors and Bioelectronics 1 (2012) 189-194.

[9] N.E. Stein, H.M. Hamelers, G. van Straten and K.J. Keesman, On-line detection of toxic components using a microbial fuel cell-based biosensor, J Process Contr 9 (2012) 1755-1761.

[10] Y. Zhang and I. Angelidaki, Submersible microbial fuel cell sensor for monitoring microbial activity and BOD in groundwater: focusing on impact of anodic biofilm on sensor applicability, Biotechnol Bioeng 10 (2011) 2339-2347.

[11] Y. Zhang, B. Min, L. Huang and I. Angelidaki, Electricity generation and microbial community response to substrate changes in microbial fuel cell, Bioresource Technol 2 (2011) 1166-1173.

[12] J.M. Tront, J.D. Fortner, M. Plötze, J.B. Hughes and A.M. Puzrin, Microbial fuel cell biosensor for in situ assessment of microbial activity, Biosensors and Bioelectronics 4 (2008) 586-590.

[13] T. Li, X. Wang, Q. Zhou, C. Liao, L. Zhou, L. Wan, J. An, Q. Du, N. Li and Z.J. Ren, Swift Acid Rain Sensing by Synergistic Rhizospheric Bioelectrochemical Responses, ACS sensors 7 (2018) 1424-1430.

[14] J. Chouler and M. Di Lorenzo, Water quality monitoring in developing countries; can microbial fuel cells be the answer? Biosensors 3 (2015) 450-470.

[15] X. Jin, X. Li, N. Zhao, I. Angelidaki and Y. Zhang, Bio-electrolytic sensor for rapid monitoring of volatile fatty acids in anaerobic digestion process, Water Res (2017) 74-80.

[16] J. Kretzschmar, C. Koch, J. Liebetrau, M. Mertig and F. Harnisch, Electroactive biofilms as sensor for volatile fatty acids: Cross sensitivity, response dynamics, latency and stability, Sensors and Actuators B: Chemical (2017) 466-472.

[17] A. Kaur, S. Ibrahim, C.J. Pickett, I.S. Michie, R.M. Dinsdale, A.J. Guwy and G.C. Premier, Anode modification to improve the performance of a microbial fuel cell volatile fatty acid biosensor, Sensors and Actuators B: Chemical (2014) 266-273.

[18] A. Kaur, J.R. Kim, I. Michie, R.M. Dinsdale, A.J. Guwy and G.C. Premier, Microbial fuel cell type biosensor for specific volatile fatty acids using acclimated bacterial communities, Biosensors and Bioelectronics (2013) 50-55. 
[19] X. Jin, I. Angelidaki and Y. Zhang, Microbial Electrochemical Monitoring of Volatile Fatty Acids during Anaerobic Digestion, Environ Sci Technol 8 (2016) 4422-4429.

[20] Y. Feng, Q. Yang, X. Wang and B.E. Logan, Treatment of carbon fiber brush anodes for improving power generation in air - cathode microbial fuel cells, J Power Sources 7 (2010) 1841-1844.

[21] G. Kvesitadze, T. Sadunishvili, T. Dudauri, N. Zakariashvili, G. Partskhaladze, V. Ugrekhelidze, G. Tsiklauri, B. Metreveli and M. Jobava, Two-stage anaerobic process for bio-hydrogen and bio-methane combined production from biodegradable solid wastes, Energy 1 (2012) 94-102.

[22] I. Angelidaki, S.P. Petersen and B.K. Ahring, Effects of lipids on thermophilic anaerobic digestion and reduction of lipid inhibition upon addition of bentonite, Appl Microbiol Biot 4 (1990) 469-472.

[23] Z. Liu, J. Liu, S. Zhang, X. Xing and Z. Su, Microbial fuel cell based biosensor for in situ monitoring of anaerobic digestion process, Bioresource Technol 22 (2011) 10221-10229.

[24] S. Freguia, K. Rabaey, Z. Yuan and J. Keller, Electron and carbon balances in microbial fuel cells reveal temporary bacterial storage behavior during electricity generation, Environ Sci Technol 8 (2007) 2915-2921.

[25] Z. Lv, D. Xie, F. Li, Y. Hu, C. Wei and C. Feng, Microbial fuel cell as a biocapacitor by using pseudo-capacitive anode materials, J Power Sources (2014) 642-649.

[26] A. Deeke, T.H. Sleutels, H.V. Hamelers and C.J. Buisman, Capacitive bioanodes enable renewable energy storage in microbial fuel cells, Environ Sci Technol 6 (2012) 3554-3560.

[27] N. Uría, X. Muñoz Berbel, O. Sánchez, F.X. Muñoz and J. Mas, Transient storage of electrical charge in biofilms of Shewanella oneidensis MR-1 growing in a microbial fuel cell, Environ Sci Technol 23 (2011) 10250-10256.

[28] J.M. Tront, J.D. Fortner, M. Plötze, J.B. Hughes and A.M. Puzrin, Microbial fuel cell biosensor for in situ assessment of microbial activity, Biosensors and Bioelectronics 4 (2008) 586-590.

[29] E. Atci, J.T. Babauta, S.T. Sultana and H. Beyenal, Microbiosensor for the detection of acetate in electrode-respiring biofilms, Biosensors and Bioelectronics (2016) 517-523.

[30] J. Kretzschmar, L.F. Rosa, J. Zosel, M. Mertig, J. Liebetrau and F. Harnisch, A Microbial Biosensor Platform for Inline Quantification of Acetate in Anaerobic Digestion: Potential and Challenges, Chem Eng Technol (2016) .

[31] M. Mehanna, P.D. Kiely, D.F. Call and B.E. Logan, Microbial electrodialysis cell for simultaneous water desalination and hydrogen gas production, Environ Sci Technol 24 (2010) 9578-9583.

[32] R.A. Rozendal, T. Sleutels, H. Hamelers and C. Buisman, Effect of the type of ion exchange membrane on performance, ion transport, and pH in biocatalyzed electrolysis of wastewater, Water Sci Technol 11 (2008) 1757-1762.

[33] S.W. Hong, I.S. Chang, Y.S. Choi and T.H. Chung, Experimental evaluation of influential factors for electricity harvesting from sediment using microbial fuel cell, Bioresource Technol 12 (2009) 3029-3035.

[34] Y. Feng, X. Wang, B.E. Logan and H. Lee, Brewery wastewater treatment using air-cathode microbial fuel cells, Appl Microbiol Biot 5 (2008) 873-880.

[35] D. Pant, G. Van Bogaert, L. Diels and K. Vanbroekhoven, A review of the substrates used in microbial fuel cells (MFCs) for sustainable energy production, Bioresource Technol 6 (2010) 1533-1543.

[36] K. Baruah and S. Hazarika, Separation of acetic acid from dilute aqueous solution by nanofiltration membrane, J Appl Polym Sci 15 (2014) .

[37] H. Liu, S. Cheng and B.E. Logan, Power generation in fed-batch microbial fuel cells as a function of ionic strength, temperature, and reactor configuration, Environ Sci Technol 14 (2005) 5488-5493. 
[38] B. Min, Ó.B. Román and I. Angelidaki, Importance of temperature and anodic medium composition on microbial fuel cell (MFC) performance, Biotechnol Lett 7 (2008) 1213-1218.

[39] J.R. Kim, B. Min and B.E. Logan, Evaluation of procedures to acclimate a microbial fuel cell for electricity production, Appl Microbiol Biot 1 (2005) 23-30.

[40] J. An, N. Li, L. Wan, L. Zhou, Q. Du, T. Li and X. Wang, Electric field induced salt precipitation into activated carbon air-cathode causes power decay in microbial fuel cells, Water Res (2017) 369-377.

[41] A.L. Ndiaye, S. Delile, J. Brunet, C. Varenne and A. Pauly, Electrochemical Sensors Based on Screen-Printed Electrodes: The Use of Phthalocyanine Derivatives for Application in VFA Detection, Biosensors 3 (2016) 46. 


\section{Figure Captions}

Figure 1. Prototype (A) and schematic diagram (B) of the MFC based biosensor.

Figure 2. Typical variation of current density of the bioreactor under different acetate concentration condition.

Figure 3. The relationship between current density of the bioreactor at a specific reaction time corresponding to different acetate concentration in the artificial AD effluent.

Figure 4. Conductivity and $\mathrm{pH}$ variation in bioreactor after 5 hours with various acetate concentrations.

Figure 5. Current density variation along with time from the biosensor corresponding to other substrates (A) and different initial temperature (B).

Figure 6. Variation of the current density of the bioreactor with $\mathrm{AD}$ effluent $(\mathrm{A})$ and the acetate concentration in AD effluent measured by the biosensor (B).

Figure 7. Acetate concentration measurement by bioreactor, current density variation (A) and results (B). The sample was 5 times diluted biogas slurry form a CSTR reactor fed with cow manure amended with different concentration of acetate. 
Table 1. Characteristics of the anaerobic digested slurry.

\begin{tabular}{llll}
\hline Parameter & Data & Parameter & Data \\
\hline TS $(\%)$ & $2.072 \pm 0.003$ & Acetic acid $\left(\mathrm{mg} \mathrm{L}^{-1}\right)$ & $278.0 \pm 10.5$ \\
VS $(\%)$ & $1.262 \pm 0.008$ & Propionic acid $\left(\mathrm{mg} \mathrm{L}^{-1}\right)$ & $17.9 \pm 0.4$ \\
pH & 8.54 & Isobutyric acid $\left(\mathrm{mg} \mathrm{L}^{-1}\right)$ & $<5$ \\
$\mathrm{EC}\left(\mathrm{mS} \mathrm{cm}^{-1}\right)$ & 17.22 & Butyric acid $\left(\mathrm{m} \mathrm{L}^{-1}\right)$ & $42.8 \pm 6.8$ \\
$\mathrm{NH}_{4}^{+}\left(\mathrm{mg} \mathrm{L}^{-1}\right)$ & $2139.3 \pm 13.8$ & Isovaleric acid $\left(\mathrm{mg} \mathrm{L}^{-1}\right)$ & $10.2 \pm 0.4$ \\
\hline
\end{tabular}


Table 2. Summary and comparison of biosensors for VFAs detection.

\begin{tabular}{|c|c|c|c|c|c|c|c|c|c|c|c|}
\hline Structure & Memb & Anode & $\begin{array}{l}\text { Electrode } \\
\text { Cathode }\end{array}$ & Reference & $\operatorname{ET}(\Omega)$ & RT & Performance & Stir & $\mathrm{T}\left({ }^{\circ} \mathrm{C}\right)$ & EM & Ref. \\
\hline H type MFC & CEM & $\begin{array}{l}\text { Carbon paper } \\
\text { with biofilm } \\
\text { Carbon paper } \\
\text { modified by } \\
\text { polypyrrole } \\
\text { with biofilm } \\
\end{array}$ & $\begin{array}{l}\text { Carbon } \\
\text { paper } \\
\text { coated Pt }\end{array}$ & $\mathrm{Ag} / \mathrm{AgCl}$ & 1000 & $\begin{array}{l}1-2 \\
\min \end{array}$ & $\begin{array}{ll} & 5-40 \\
& \mathrm{mg} \\
\text { Acetate, } & \mathrm{L}^{-1} \\
\text { propionate, } & \\
\text { and butyrate } & 0-60 \\
& \mathrm{mg} \\
& \mathrm{L}^{-1}\end{array}$ & $\begin{array}{l}\text { Magnetic } \\
\text { stirring }\end{array}$ & 30 & $\mathrm{CV}$ & {$[18]$} \\
\hline Single chamber & 1 & $\begin{array}{l}\text { SPEs (DRP } \\
\text { C110 and DRP } \\
\text { C220AT) }\end{array}$ & 1 & $\mathrm{Ag}$ & 1 & $\begin{array}{l}<2 \\
\min \end{array}$ & $\begin{array}{l}\text { Acetate: } \\
\text { DRP C110: } 100- \\
400 \mathrm{mM} \\
\text { DRP C220AT in } \\
\mathrm{KCl}: 50-300 \mathrm{mM}\end{array}$ & 1 & Room & $\begin{array}{l}\text { CV } \\
\text { SWV }\end{array}$ & [41] \\
\hline $\begin{array}{l}\text { A disposable } \\
\text { borosilicate glass } \\
\text { pasteur pipette }\end{array}$ & 1 & $\begin{array}{l}\text { Carbon fiber } \\
\text { with biofilm }\end{array}$ & 1 & $\mathrm{Ag} / \mathrm{AgCl}$ & 1 & $\begin{array}{l}<2 \\
\min \end{array}$ & $\begin{array}{l}\text { Acetate: } \\
\text { LDR: } 0.05-1.6 \mathrm{mM}\end{array}$ & 1 & 30 & Current & [29] \\
\hline Single chamber & 1 & $\begin{array}{l}\text { Graphite rods } \\
\text { with biofilm }\end{array}$ & $\begin{array}{l}\text { Graphite } \\
\text { rods }\end{array}$ & $\mathrm{Ag} / \mathrm{AgCl}$ & 1 & $\begin{array}{l}\text { CV: } \\
1.3 \\
\mathrm{~h} \\
\mathrm{CA}: \\
180 \\
\mathrm{~s}\end{array}$ & $\begin{array}{l}\text { Acetate: } \\
0.5-5 \mathrm{mM}\end{array}$ & $\begin{array}{l}\text { Magnetic } \\
\text { stirring }\end{array}$ & 38 & $\begin{array}{l}\mathrm{CV} \\
\mathrm{CA}\end{array}$ & {$[16,30]$} \\
\hline $\begin{array}{l}\text { Three chamber } \\
\text { MDC }\end{array}$ & $\begin{array}{l}\text { AEM } \\
\text { CEM }\end{array}$ & $(3)=$ & $\begin{array}{l}\text { Stainless } \\
\text { mesh }\end{array}$ & 1 & 1000 & $5 \mathrm{~h}$ & $\begin{array}{l}\text { Total VFAs: } \\
1-200 \mathrm{mM}\end{array}$ & & & & [19] \\
\hline $\begin{array}{l}\text { Double chamber } \\
\text { MEC }\end{array}$ & AEM & $\begin{array}{l}\text { Carbon brush } \\
\text { with biofilm }\end{array}$ & $\begin{array}{l}\text { Titanium } \\
\text { woven } \\
\text { wire mesh } \\
\text { coated Pt }\end{array}$ & 1 & 10 & $1 \mathrm{~h}$ & $\begin{array}{l}\text { Total VFAs: } \\
0-100 \mathrm{mM}\end{array}$ & $\begin{array}{l}\text { Magnetic } \\
\text { stirring in } \\
\text { anode }\end{array}$ & $22 \pm 2$ & Current & {$[15]$} \\
\hline $\begin{array}{l}\text { Double-chamber } \\
\text { MFC }\end{array}$ & AEM & $\begin{array}{l}\text { Carbon brush } \\
\text { with biofilm }\end{array}$ & $\begin{array}{l}\text { Graphite } \\
\text { plate } \\
\text { coated Pt }\end{array}$ & 1 & 10 & $\begin{array}{l}1-5 \\
h\end{array}$ & $\begin{array}{l}\text { Acetate: } \\
0-20 \mathrm{mM}\end{array}$ & 1 & $22 \pm 2$ & Current & $\begin{array}{l}\text { Present } \\
\text { study }\end{array}$ \\
\hline
\end{tabular}


AEM: Anion exchange membrane

CEM: Cation exchange membrane

CV: Cyclic voltammetry

CA: Chronoamperometry

EM: Electrochemical measurement

ER: External resistance

LDR: Linear dynamic range

MDC: Microbial desalination cell

MEC: Microbial electrolysis cell

MFC: Microbial fuel cell

Memb: Membrane

RT: Response time

SWV: Square wave voltammetry

SPEs: Screen-printed electrodes

$\mathrm{T}$ : Temperature

VFAs: Volatile fatty acids 


\section{Highlights}

- MFC based biosensor for acetate monitoring in AD process with high accuracy.

- Linear detection range of $0.5-20 \mathrm{mM}$ established within 5 hours response.

- High selectivity to acetate and less interference from other VFAs.

- Digestate with temperature of $37^{\circ} \mathrm{C}$ had no significant influence on biosensor. 


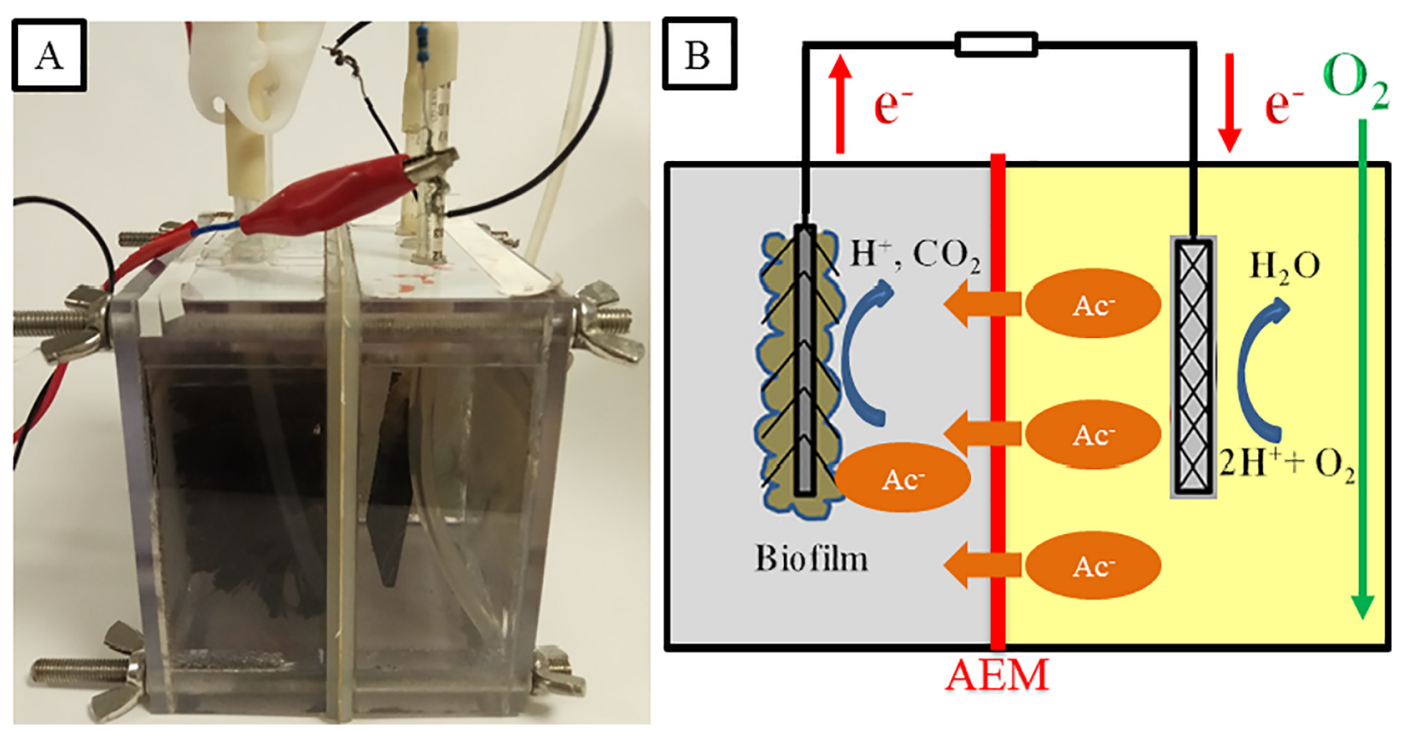

Figure 1 

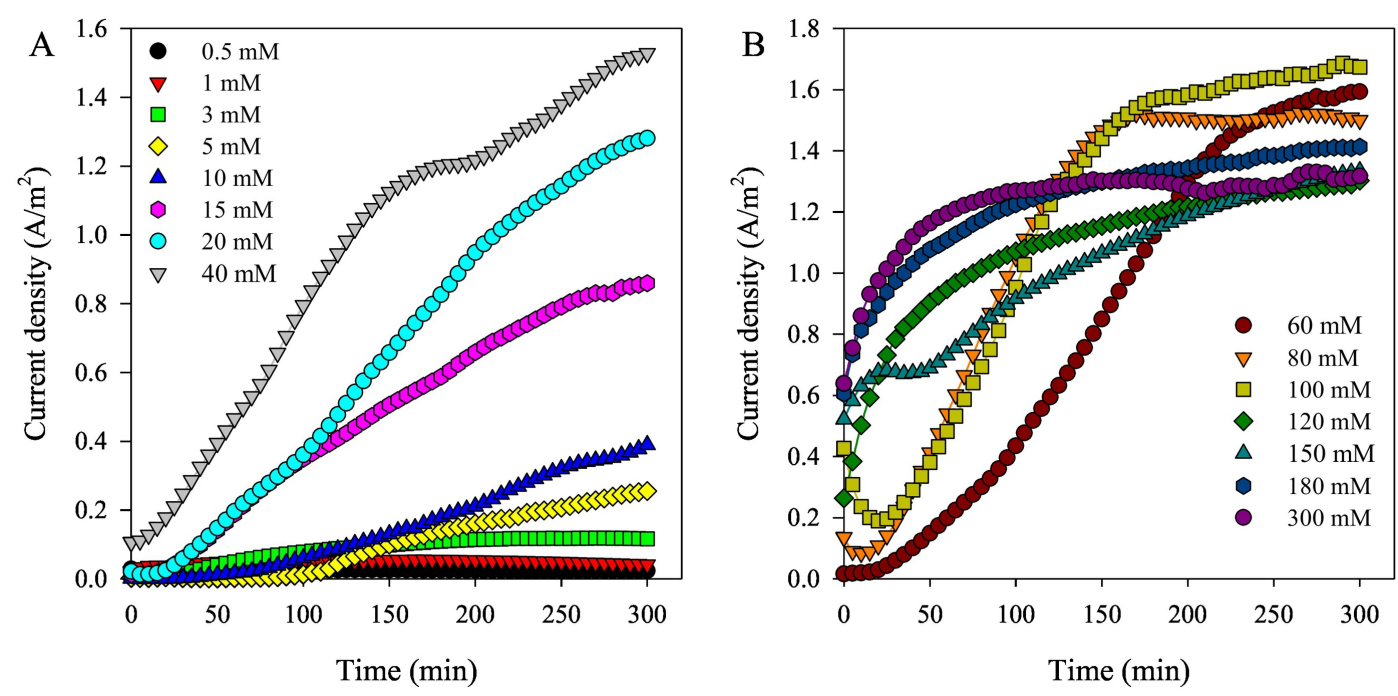

Figure 2 

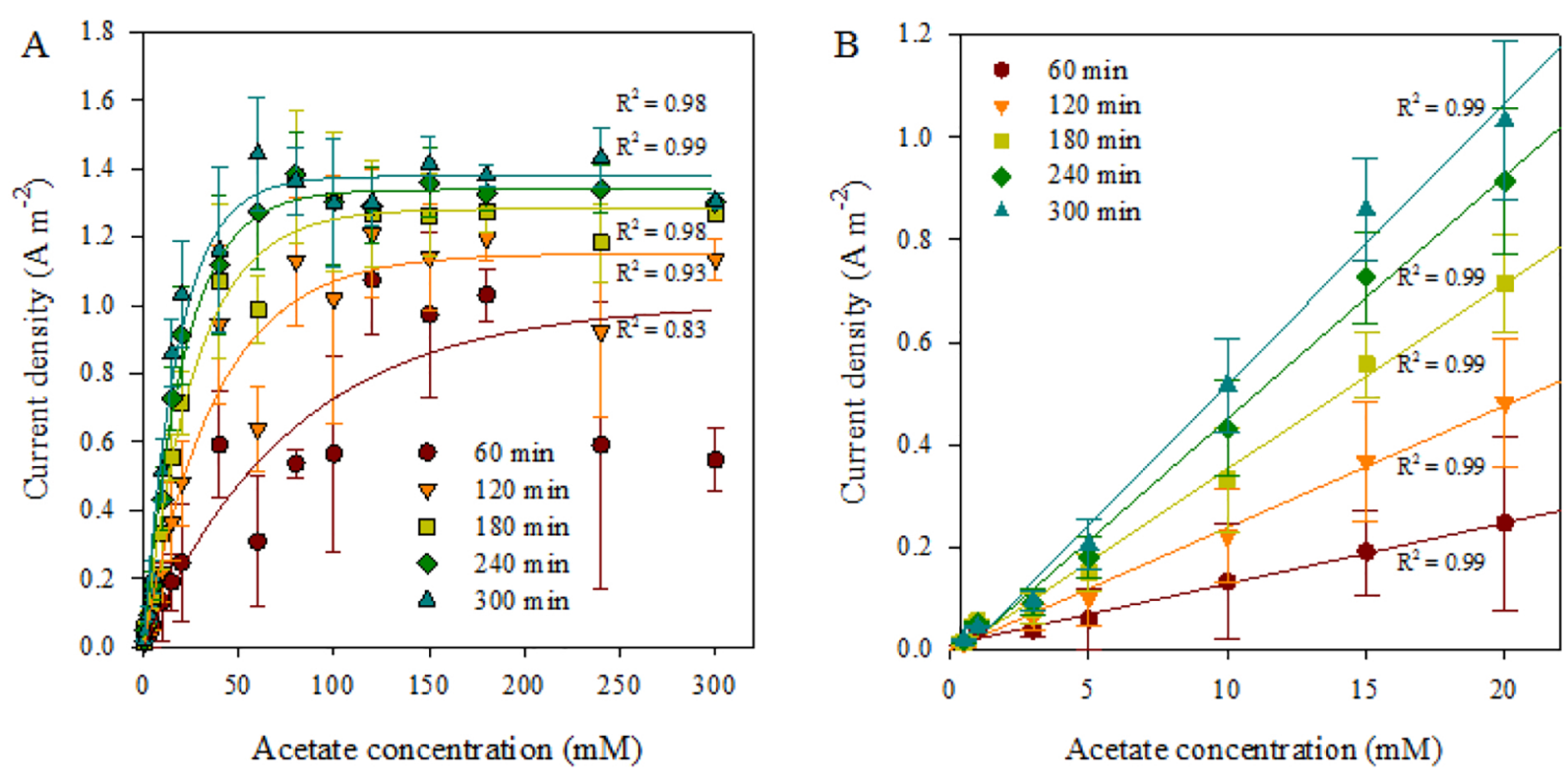

Figure 3 

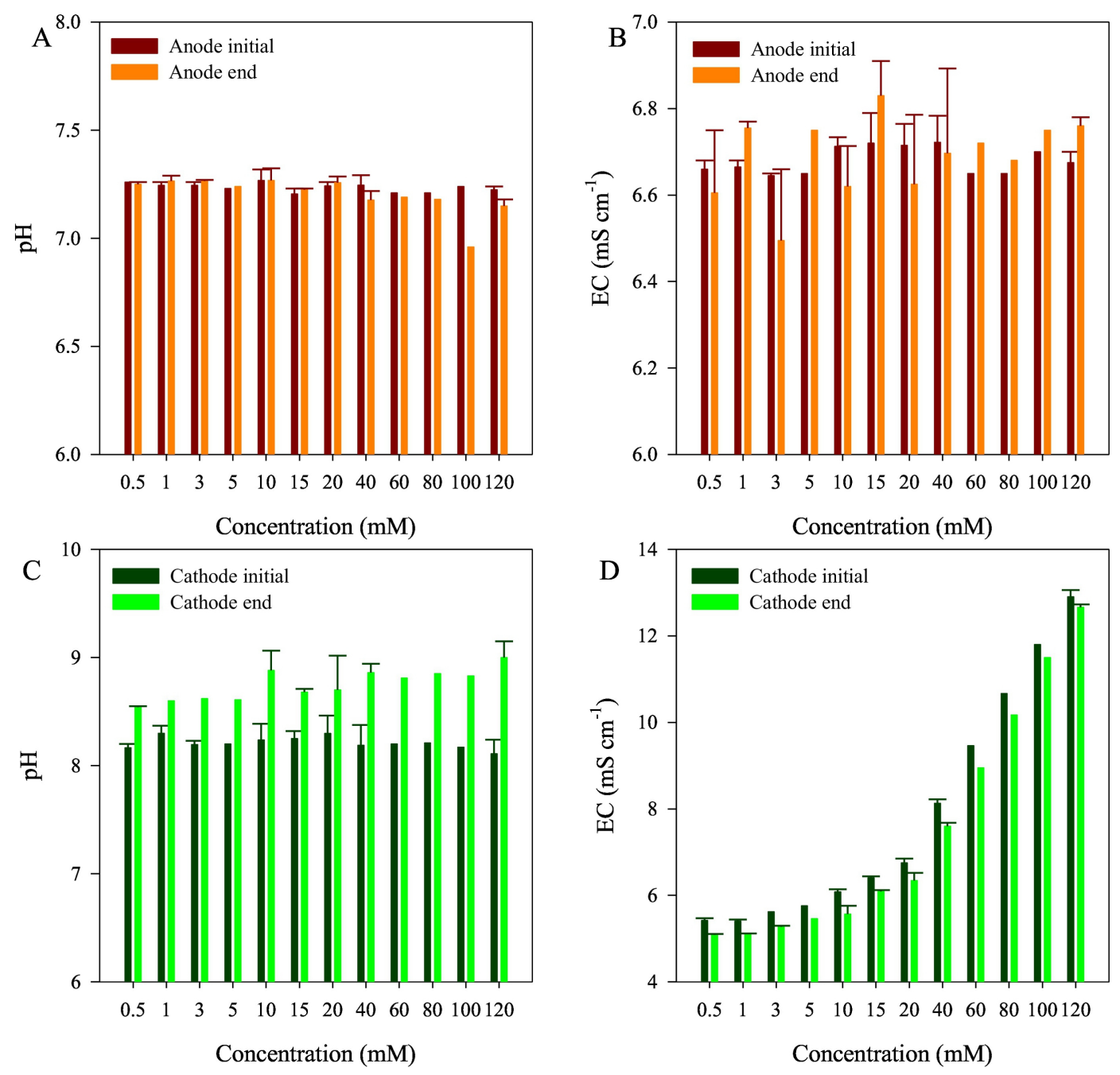

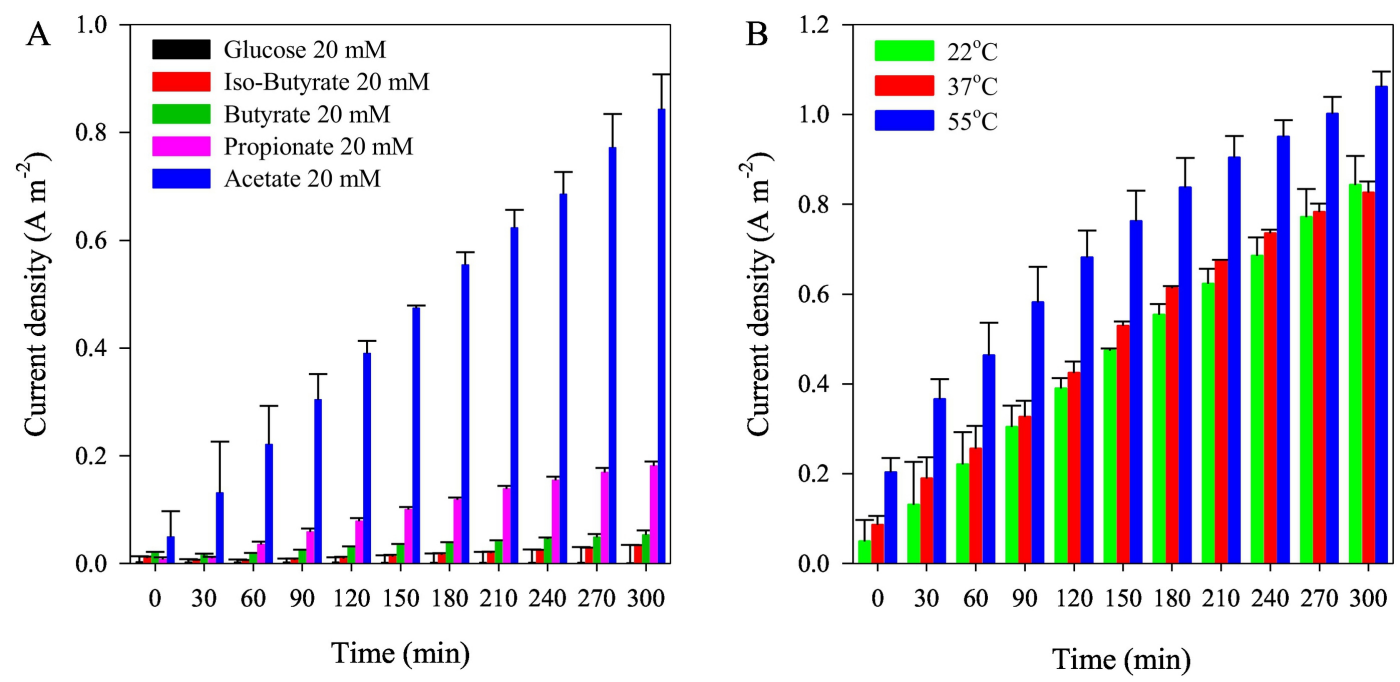

Figure 5 

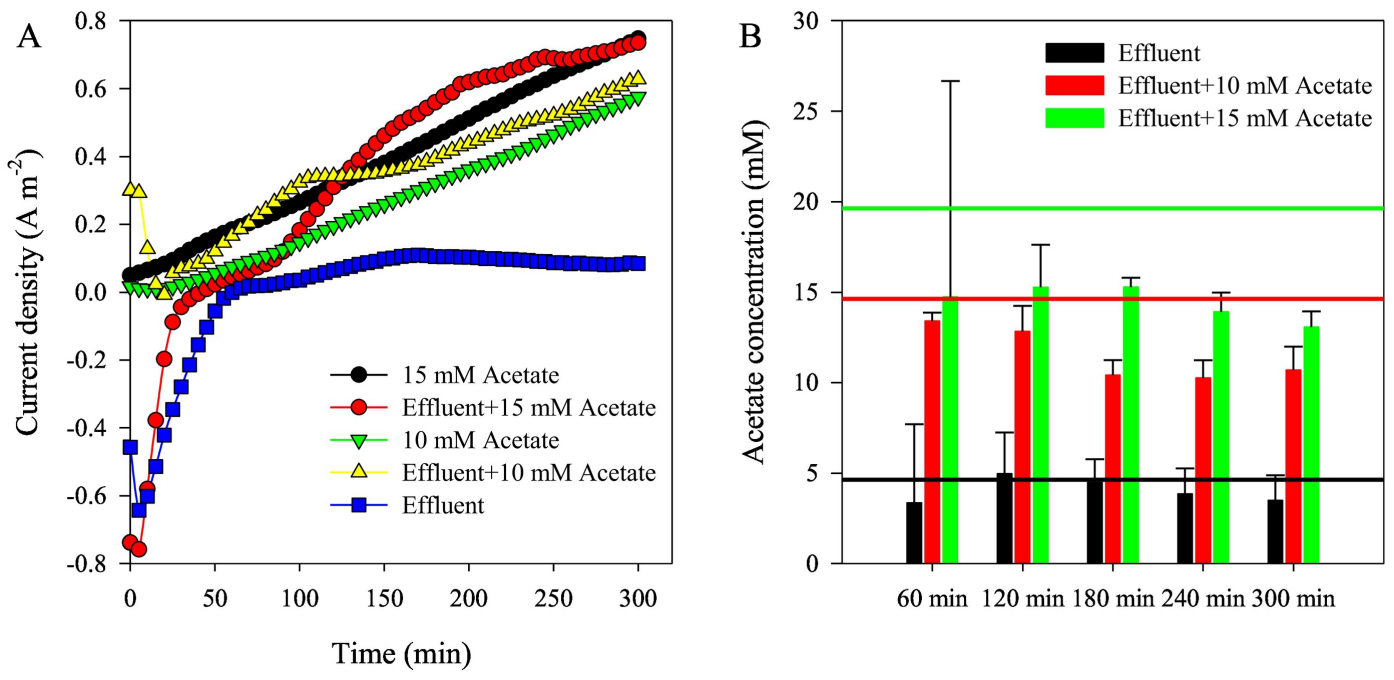

Figure 6 

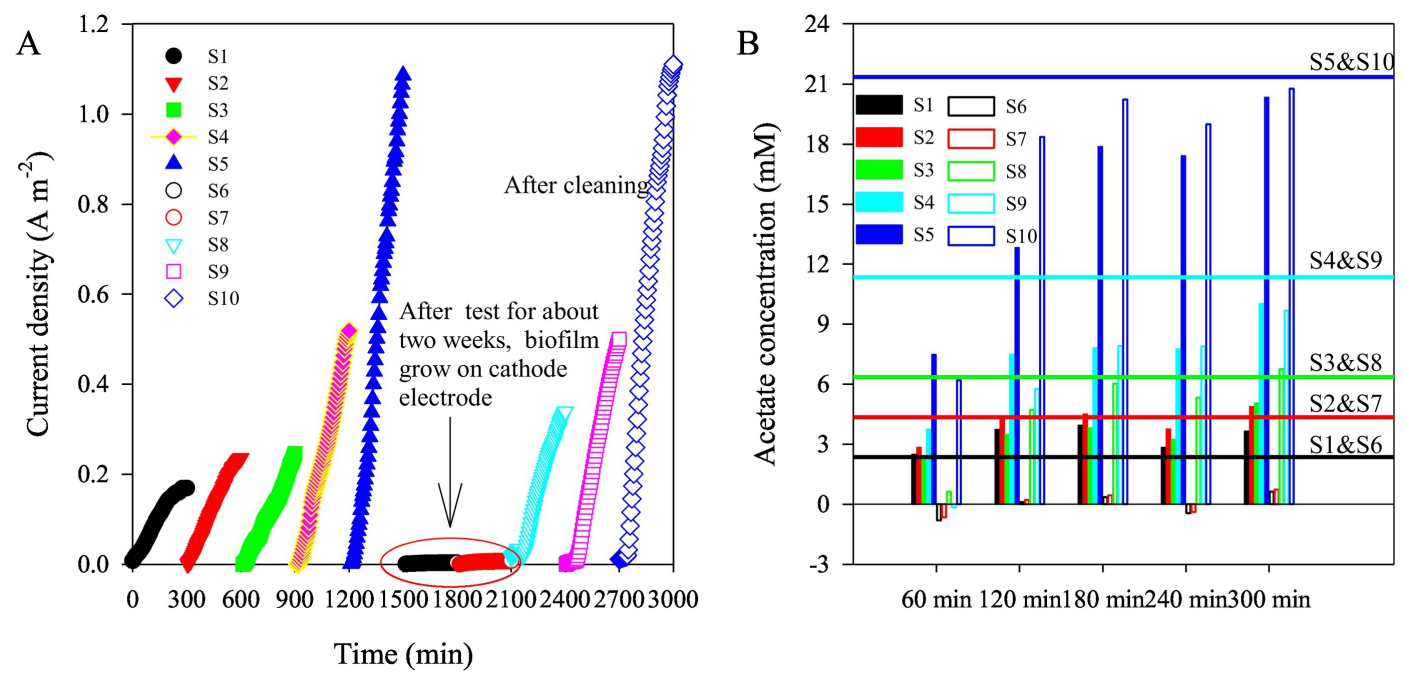

Figure 7 